\title{
Some Issues in Treating the Changes of Circumstances under English Law
}

\begin{abstract}
All legal systems have their own solution for the treatment of the essential change of circumstance subsequent to the conclusion of the contract. Some of them allow for the judicial amendment of the contract, if the conditions of the clausula rebus sic stantibus are fulfilled. There are other states, where the possibility to modify the contract by judicial act in case of an essential change of circumstances subsequent to the contract conclusion has only recently been recognised by the national legislation. In the following, it is to be reviewed how and by what means and models English law treats those changes of circumstances which occur after the conclusion of the contract and significantly reshape the contractual relationships.
\end{abstract}

Keywords: change of circumstances, clausula rebus sic stantibus, hardship, frustration of contract, Brexit, coronavirus

\begin{abstract}
ABSZTRAKT
A szerződéskötést követöen a körülményekben bekövetkező lényeges változások figyelembe vételére és kezelésére valamennyi jogrendszeren belül kialakultak álláspontok. A különbözö jogintézmények, alkalmazott megoldások bár sok szempontból hasonlatosak, azonban számos eltérés is megfigyelhetó. A tanulmány átfogóan mutatja be, hogy az angol jog miként kezeli a körülménybeli változásokat és azok szerződésekre kifejtett hatását. Ennek során bemutatásra kerül a szerződés meghiúsulásának tana (frustration of contract) és az elmélet kialakulásának alapjául szolgáló, bírósági esetjog.
\end{abstract}

Kulcsszavak: körülmények utólagos megváltozása, clausula rebus sic stantibus, hardship, szerződés meghiúsulása, frustration, Brexit, koronavírus

The judgment and treatment of the changes in circumstances belongs to the field of contract law. Though the obligation law rules, including contract law provisions, provide the dynamics of civil law, the various legal transactions and contracts to be concluded basically reflect a given time, since the rights and duties of the contractual parties are fixed with regard to those circumstances which exist at the time of the contract's conclusion. However, changes can occur in the circumstances of the contract, which can impact on the durable contractual relationship existing between the parties, including their rights and duties, and particularly on the duty to fulfil the contract.

All legal systems have their own solution for the treatment of the essential change of circumstance subsequent to the conclusion of the contract. Some of them allow for the judicial amendment of the contract, if the conditions of the clausula rebus sic

\footnotetext{
* Dr. Ágnes Juhász, senior lecturer, University of Miskolc (Hungary) Faculty of Law Department for Civil Law, civagnes@uni-miskolc.hu.
} 
stantibus are fulfilled. ${ }^{1}$ There are other states, where the possibility to modify the contract by judicial act in case of an essential change of circumstances subsequent to the contract conclusion has only recently been recognised by the national legislation. Moreover, it is also noteworthy that these relatively new regulations bind the application of the contract amendment by judicial act to strict limits. ${ }^{2}$

It is typical that the essential change of circumstances and its effects on the contractual relationship attracted more and more attention from the legislation and the jurisprudence, when historic events having a global impact occurred. It was after the World War I when the modern jurisprudence examined ${ }^{3}$ the problem thoroughly. ${ }^{4}$ Afterwards, the Great Depression in 1929 and its effects and consequences made it clear that the changes occurred in the contractual relationship because of the essential change of circumstances, i.e. the effect of such changes on the position of the contractual parties does require particular attention.

However, another segment of national legislators failed to take any actions in spite of the recognition mentioned above and, based on various dogmatic considerations, considers the binding force of contract as priority and keeps the obligation to fulfil the contract in mind. In other countries, for instance in Hungary, clausula rebus sic stantibus is declared as an exemption from the principle pacta sunt servanda.

The demand for the application of the clausula and for the regulation of the contract amendment by judicial act arose again after the global economic crisis in 2008. Notwithstanding the fact that this newer recession is not comparable to the economic crisis in 1929, the detrimental changes which occurred in the contractual relationships due to the crisis and which often broke the contractual balance, increasingly raised the need to create a solution via legislative means.

However, the answers of the different countries to the changes in circumstances after the conclusion of the contract vary widely and one difference is whether the solution to be applied is based on statute law or it was developed by the case-law of the courts.

Hondius and Grigoleit examined the effect of the change of circumstances on the contractual relationship in the European countries and they distinguished, with respect to the legislative and judicial recognition of this effect, between open and

${ }^{1}$ Cf. Act No. V of 2013 on the Civil Code, Art. 6:192.

2 In 2016, the Code Civil was amended according to the French civil law reform. The reworded text of Article 1195 relating to the binding force of contract, enables the contractual parties to renegotiate the contract if its performance became excessively onerous due to the an unforseenable change of circumstances. In case of refusal or the failure of renegotiations, the parties may agree to terminate the contract. In the absecnce of such agreement, the court may, on the request of a party, revise the contract or put an end to it. Partly in parallel with the French reform, the Romanian civil code, modelled on the Code Napoleon, had also been revised. The new code, which came into effect in 2011, regulates the judicial amendment of contract as an exceptional legal institution, under the expression "impreviziune."

${ }^{3}$ From the relating literature see Krückmann, Paul: Clausula rebus sic stantibus, Kriegsklausel, Streikklausel. Archiv für die civilistische Praxis, 1918/2-3, 157-481; Almási, Antal: A gazdasági lehetetlenülés térhódítása. Jogtudományi Közlöny, 1922/15, 113-115; Schuster, Rudolf: Néhány szó a gazdasági lehetetlenülés kérdéséhez. Jogtudományi Közlöny, 1923/1, 2-4.

${ }^{4}$ Oosterhuis, Janwillem: Unexpected Circumstances Arising from World War I and Its Aftermath: Open versus Closed Legal Systems. Erasmus Law Review, 2014/2, 67-79. (doi: 10.5553/elr.000018). 
closed legal systems. ${ }^{5}$ In countries classified as open legal systems (e.g. Germany, Austria, Greece, Italy, Lithuania, the Netherlands, Portugal, Spain and Sweden) unforeseen changes of circumstances are defined both in the relating legal regulation and in the judicial practice as a general exemption, upon which the contractual parties are allowed to adopt their contract to the changed circumstances.

On the contrary, in the closed legal systems (e.g. Belgium, Czech Republic, Denmark, England, France, Ireland, Scotland and Slovenia) there is no similar solution. There are several arguments to explain this. On the one hand, there are countries, where the clausula is not declared by the civil law rules. On the other hands, there are other countries where the clausula is known in the judicial practice, but the possibility to adapt the contract to the changed circumstances has not been generally recognised.

Nevertheless, albeit its illustrative nature, the distinction between open and closed legal systems is purely theoretical and therefore it is less suitable for showing in a certain case the differences existing between the solutions applied by the various countries. ${ }^{6}$

As mentioned before, during the development of the private law, several legal institutions have been evolved in the laws of the various states for the treatment of the effects of the changes of circumstances on the contractual relationship. ${ }^{7}$ Such an example is the theory of imprevision ("théorie de l'imprévision") in the French civil law, while the treatment of the changes in circumstances are regulated from the obligation law reform of 2002 within the rules on the collapse of the underlying basis of the transaction ("Störung des Geschäftsgrundlage") by the German civil code. ${ }^{8}$

In Italian civil law, there are also some provisions which deal with the effects of the change of circumstances on the contractual relationship. ${ }^{9}$ The adoption of these rules was partly due to the events which occurred in the first part of the $20^{\text {th }}$ century. Moreover, Italian civil law at that time was strongly influenced by German private law jurisprudence, such as Windscheid's doctrine of tacit presupposition ("Lehre von der Voraussetzung") and the theories of Oertmann and Larenz as well. ${ }^{10}$

\footnotetext{
${ }^{5}$ Hondius, Ewoud: Change of circumstances: the Trento project. In: Castermans, Alex Geert-Jansen, Kasper J. O.-Knigge, Marte W.-Memelink, Pauline-Nieuwenthuis, Jacob Hans (eds.): Foreseen and unforeseen circumstances. Kluwer, Deventer, 2012, 115-133; Hondius, Ewoud-Grigoleit, Christoph: Introduction: An approach to the issues and doctrines relating to unexpected circumstances. In: Hondius, Ewoud-Grigoleit, Christoph (eds.): Unexpected Circumstances in European Contract Law. Cambridge University Press, Cambridge, 2011, 10-11. (doi: 10.1017/cbo9780511763335.004).

${ }^{6}$ Hondius: op. cit., 119; Hondius, Ewoud-Grigoleit, Christoph: General comparative remarks: Converging tendencies, remaining differences and the unsolved mystery of adjustment. In: Hondius, Ewoud-Grigoleit, Christoph (eds.): Unexpected Circumstances in European Contract Law. Cambridge University Press, Cambridge, 2011, 643-644. (doi: 10.1017/cbo9780511763335.010).

${ }^{7}$ The various models of the treating of the changes in circumstances are comprehensively examined by Rodrigo Uribe Momberg. See Momberg, Rodrigo Uribe: The effect of a change of circumstances on the binding force of contracts: Comparative perspectives. Intersentia, Cambridge-Antwerpen-Portland, 2011.

${ }^{8}$ Cf. BGB, Art. 313.

${ }^{9}$ Cf. Codice civile, Art. 1467-1468.

10 Windscheid, Bernhard: Die Lehre des römischen Rechts von der Voraussetzung. Düsseldorf, 1850; Oertmann, Paul: Die Geschäftsgrundlage - Ein neuer Rechtsbegriff. 1921; Larenz, Karl: Geschäftsgrundlage und Vertragserfüllung: die Bedeutung „veränderter Umstände” im Zivilrecht. Beck, München, 1957. The theories of
} 
In English law, the essential change of circumstances subsequent to the contract conclusion raises the applicability of several legal institutions, e.g. hardship, frustration of contract, impossibility and impracticability. In this context, it is to be noted that the aforementioned legal institutes appear differently in English and American law. Though the solutions applied by American law are based on English law traditions, due to the diverse development of the law, there are now significant differences between the legal institutions to be applied and their conditions and legal effects. ${ }^{11}$

It is important to note that the legal institutions appeared in the various national civil laws have several similarities and they correspond more or less to each other. Nevertheless, they are not absolutely identical.

On the one hand, it can be explained by the systemic differences of the various states, i.e. if a given state belongs to the Anglo-Saxon or a continental legal system. On the other hand, the divergent developmental tendencies of the continental legal system (Germanic or French tradition) and the dogmatic differences also explains the greater or lesser diversions of the various legal institutions. ${ }^{12}$

In the following, it is to be reviewed how and by what means and models English law treats those changes of circumstances which occur after the conclusion of the contract and significantly reshape the contractual relationships.

\section{The theory of frustration of contract}

The demand for treating the effects of the changes of circumstances on the contractual relationship and for treating the situation that evolved due to these changes arose in continental law relatively early. Similarly, this demand also appeared in English law, since the various national legislators intended to react to the same problems, e.g. the negative impact of the world wars. ${ }^{13}$ Nevertheless, it is noteworthy that the above- mentioned demand arose much earlier in English law, during the 1700s, than in continental law. In the judicial practice, the impacts of the effects

Windscheid and Oertmann are reviewed in detail by Lukács, Nikolett: A clausula rebus sic stantibus elvének megjelenése a német pandektisták felfogásában. In: Smuk, Péter (ed.): Az állam és jog alapvető értékei. Széchenyi István Egyetem Állam- és Jogtudományi Doktori Iskola, Györ, 2010, 322-326. About the in-depth assessment and comparison of the expression "foundation of the transaction" created and used by Oertmann and Larenz see Dudás, Attila: A szerződés célja (kauzája) az európai és a magyar jogban. A szerződés kauzájának fogalma az európai jogelméletben. Acta Universitatis Szegediensis, Acta Juridica et Politica, 2012/2, 91. The Pandectists' impact on Italian law, by the citation of the relating judicial practice, is comprehensively overviewed in the German private law literature by Reiter, Christian: Vertrag und Geschäftsgrundlage im deutschen und italienischen Recht: Eine rechtsvergleichende Untersuchung. Mohr Siebeck, Tübingen, 2002, 48-78.

${ }^{11}$ Cf. Eisenberg, Melvin: Impossibility, Impracticability and Frustration. Journal of Legal Analysis, 2009/1, 207261. (doi: 10.4159/jla.v1i1.12) About the American approach to the doctrine see Momberg: op. cit., 160-184.

12 Bazil Oglindă represents another approach, when he treats the above mentioned legal institutions equal. See Oglindă, Bazil: The Theory of Imprevision in the Context of the Economic Crisis and the New Romanian Civil Code (NCC). Perspectives of Business Law Journal, 2012/1, 250. About the different legal institutions see in detail Juhász, Ágnes: A szerződésmódositás kérdésköre a magyar polgári jogban. Wolters Kluwer, Budapest, 2019, 142-182.

${ }^{13}$ Cf. MacMillan, Catharine: English Contract Law and the Great War: The Development of a Doctrine of Frustration. Comparative Legal History, 2014/2, 278-302. (doi: 10.5235/2049677x.2.2.278). 
of the changes of circumstances can be treated according to the theory known as frustration of contract.

At first sight, this theory is very similar to other legal institutions which appear in continental laws. Nonetheless, there are several differences regarding the content of these legal institutions. According to Rösler, the similarity between the theory of frustration of contract and the various solutions which appear in continental laws is evident. ${ }^{14}$ Zimmermann goes further, and states that the doctrine of frustration of contract and the legal solution declared in Article 313 of the BGB ("collapse of the underlying basis of the transaction") are not only similar, but functionally equivalent with regard to their aim. ${ }^{15}$

The binding force of contract and its sanctity had practically not been controversial in English law until the middle of the $19^{\text {th }}$ century. According to the doctrine of absolute contracts, contractual duties were regarded as absolute, in the sense that supervening events provided no excuse for non-performance ${ }^{16}$ regardless of the nature of the change. It meant that the contractual parties had to fulfil the contract even if changes occurred in the circumstances subsequent to the conclusion of the contract.

It is quite visible that the English law approach to the changes of circumstances was similar to continental law, which were based on the Roman law principle, pacta sunt servanda. However, while German, French and Italian law knew an exceptional clause (clausula rebus sic stantibus) from the principle declaring the binding force of contracts, even if it was not recognised by legislation, the above-mentioned clause rooted in the Middle Ages was entirely unknown in English law. ${ }^{17}$ Instead of this, the doctrine of frustration of contract dedicated to treat the effects of the changes of circumstances on the contractual relationship had been developed alongside various precedents and had been accepted as we know it now. In the course of this development process, various cases and events were outlined, which cause the essential change of circumstances and thereby lead to the frustration of contract and absolve the contractual parties from the duty to fulfil the contract. (Such event can be the failure of an anticipated event, the outbreak of a war, the subsequent illegality and so on.)

In its extensive work, Peel examines the doctrine of frustration of contract thoroughly and determines several types and subtypes of frustrating events, such as impossibility, frustration of purpose or illegality. Supervening impossibility can arise in various ways, e.g. as a result of the whole or partial destruction of a particular thing or of the death or incapacity of either party in the case of certain "personal" contracts. Impossibility can also arise, when the subject-matter of contract, or a thing or person essential for the purpose of its performance does not cease, but becomes unavailable for that purpose. ${ }^{18}$

\footnotetext{
${ }^{14}$ Rösler, Hannes: Hardship in German codified private law - In Comparative Perspective to English, French and International Contract Law. European Review of Private Law, 2007/4, 499.

${ }^{15}$ Zimmermann, Reinhard: The Law of Obligations: Roman Foundations of the Civilian Tradition. Oxford University Press, Oxford, 1996, 582.

${ }^{16}$ Peel, Edwin: Treitel on The Law of Contract. Sweet and Maxwell, London, 2011, 920.

${ }^{17}$ Rösler: op. cit., 497; Zimmermann: op. cit., 579.

18 Peel: op. cit., 929.
} 
Although the above-mentioned classification contains several types of frustrating events, it is important to state that there is no numerus clausus, i.e. there is no limited class of frustrating events. Over time, the number of these events has constantly been changing, sometimes faster, sometimes slower. At the beginning of the development of the theory, there was an extension, i.e. the number of judgments, in which the frustration of contract by a certain event was recognised, increased. Later, the initial frames started to narrow and there were cases where frustration was successfully pleaded, but later, these were overruled..$^{19}$ Nowadays, the evolution and alteration of the doctrine is still ongoing, though its pace is much slower. Nevertheless, the question of frustration comes back time and again, which requires the courts to deal with and judge these cases.

In the following, I review the beginning of the development process of the abovementioned doctrine by the presentation of the relating precedents.

\subsection{The case of Paradine $v$ Jane}

The approach, which emphasised the binding force of contract was based on a precedent which originated in the $17^{\text {th }}$ century.

As evidenced by the facts of the case Paradine $v$ Jane, ${ }^{20}$ a building rental contract was concluded between the contractual parties. However, the land was invaded by the enemy of the King and Jane was forced to leave the building. Since Jane could not use the building and could not take benefits, he refused to pay the fee to Paradine, who brought an action against Jane and claimed the court to oblige Jane to pay the rent arrears.

As it was stated by the court, where a party brings a duty or charge upon himself by virtue of a contract, he is bound to perform the duty or pay the charge, notwithstanding any event, for which the party could have inserted a clause in the contract, which would prescribe what is to be done in case of an event. The party's duty to fulfil the contract, as well as his liability in case of the infringement of this duty, is absolute in nature. ${ }^{21}$ Therefore, the court held that Jane was bound to pay the fee to Paradine, despite the fact that the land was temporarily invaded by the enemy, i.e. Jane was not released from his obligation.

Though the court did not expressly deal with the question of impossibility, William Page emphasises that the case Paradine $\mathrm{v} \mathrm{Jane}^{22}$ shall undoubtedly be deemed as

${ }^{19}$ E.g. Carapanayoti \& Co. Ltd. v. E. T. Green. Ltd. [1959] 1 Q.B. 131, overruled in Tsakiroglou \& Co Ltd v Noblee Thorl GmbH [1962] AC 93.; Government of Ceylon v Société Franco-Tunisienne D'Armement-Tunis ("The Massalia") (No 2) [1960] 2 Lloyd1s Rep 352, overruled in Ocean Tramp Tankers Corp v V/O Sovfracht (“The Eugenia") [1964] 2 QB 226.

${ }^{20}$ Paradine v Jane [1647] EWCH KB J5.

${ }^{21}$ Cf. Beale, Hugh: Adaptation to Changed Circumstances, Specific Performance and Remedies. Report on English Law. In: Harmathy, Attila (ed.): Binding Force of Contract. MTA-JTI, Budapest, 1991, 9-24.

22 In English law, Paradine $v$ Jane was often misunderstood. The negative effects of this misinterpretation on English legal dogma was highlighted by Wade, William: The Principle of Impossibility in Contract. Law Quarterly Review, 1940/56, 524. 
a milestone in the developmental process of the English law approach to the impossibility of the contract. ${ }^{23}$

\subsection{Taylor v Caldwell}

The strict and rigid approach of the courts to the binding force of the contract seemed to soften during the $19^{\text {th }}$ century. The first stage of this process was the case of Taylor $v$ Caldwell in $1863,{ }^{24}$ in which the doctrine of frustration of contract was firstly enunciated. (It is noteworthy that some authors mentioned it as the doctrine of impossibility of performance. ${ }^{25}$

According to the facts described, the plaintiff, Taylor, hired out the Surrey Gardens and Music Hall from the defendant, Caldwell, to use it for the series of "grand concerts" enriched by visuals. Taylor took all the risks of organising the concerts, of signing of the artists and so on. Just prior to the scheduled date for the first concert, the music hall was destroyed by an accidental fire and the concerts planned and already organised by Taylor could not been held.

Taylor brought an action against Caldwell by reference to breach of contract. Taylor considered that Caldwell could not fulfil his contractual duty because of the destruction of the building and therefore he claimed compensation for damages incurred due to the breach of contract.

As Justice Blackburn formulated that "(...) in contracts in which the performance depends on the continued existence of a given person or thing, a condition is implied that the impossibility of performance arising from the perishing of the person or thing shall excuse the performance." Accordingly, the burning to the ground of the music hall lead to the impossibility of the contract, which excused the contracting parties from performing the contract. ${ }^{26}$

The case Taylor $v$ Caldwell is precedential for the practice of the fulfilment of contractual duties and of the excuse from them, since it derives from the previous, more than two-hundred-old practice. With the application of the fiction of an implied condition, Justice Blackburn created an exemption from the binding force of contract declared in Paradine $v$ Jane, without derogating from the previous judicial practice. ${ }^{27}$ Nevertheless, it is another question that the exemption had been more broadly interpreted in the judgments after Taylor $v$ Caldwell than it was originally intended. ${ }^{28}$ Thus, the

${ }^{23}$ Page, William Herbert: The Development of the Doctrine of Impossibility of Performance. Michigan Law Review, 1920/7, 589-614. (doi: 10.2307/1278026).

24 Taylor v Caldwell [1863] EWCH QB J1.

${ }^{25}$ Cf. Brown, Charles G.: The Doctrine of Impossibility of Performance and the Foreseeability Test. Loyola University Chicago Law Journal, 1975/3, 575-593.

26 The doctrine of implied condition arises several theoretical and practical problems, therefore its applicability was hardly criticized not only in the past, but in the contemporary legal jurisprudence. See Trakman, Leon E.: Frustrated Contracts and Legal Fictions. The Modern Law Review, 1983/1, 39-55. (doi: 10.1111/j.14682230.1983.tb02506.x).

${ }^{27}$ McElroy, R. G.-Williams, Glanville: The Coronation Cases I. Modern Law Journal, 1941/4, 242. (doi: 10.1111/ j.1468-2230.1940.tb00777.x).

28 Ibid. 
scope of the exemption was considerably limited by the judgment in the case Taylor $\checkmark$ Caldwell, since the impossibility of contract could have been based only on certain changes of circumstances, like the death or incapacity of the obligor, the occurrence of changes in circumstances, and the destruction either of the subject matter of contract or other thing, which is essential regarding the fulfilment of the contract. ${ }^{29}$

\subsection{Coronation cases}

The exemption formulated in Taylor $v$ Caldwell was the base of the judgment held in Krell v Henry in $1902,{ }^{30}$ which is arguably the best-known among the so-called coronation cases relating to the procession of King Edward VII that was cancelled due to his ill health.

As evidenced by the facts of the case, Henry hired rooms at Paul Krell's flat in Pall Mall, in London, to view from its windows the coronation procession of King Edward VII, which would pass along Pall Mall. After the conclusion of the contract, the King became seriously ill and therefore the ceremony was cancelled just two days before the coronation. ${ }^{31}$ (The coronation was held much later, more than one year after the originally scheduled date.)

Henry paid a £25 deposit, but did not pay the fee for the room, because he could not use the flat. Krell brought an action against Henry and claimed the outstanding $£ 50$. The court decided in favour of Henry and relieved him from paying the rest of money. As it was stated, the inspecting of the coronation procession was the foundation of the contract, though the contract contained no reference to the coronation. At this point, it is worth invoking the stand of Justice Blackburn formulated in Taylor v Caldwell, in which he stated that the object of the contract should permanently exist.

Regarding the facts evidenced in Krell v Henry, it can be stated that the subject matter of contract did not change, inasmuch as the rooms to be hired by Henry still existed and they were in unchanged state, i.e. they were identical. In a legal sense, the impossibility of the fulfilment of the contract did not occur. Nevertheless, the subject matter of the contract, or more precisely, the essential character of the subject matter of contract changed due to the change of circumstances. As Lord Atkin explained, "It]he subject matter of the contract was 'rooms to view the procession', but the postponement mad the rooms not rooms to view the procession." ${ }^{32}$ As Wade

${ }^{29}$ Cf. Appleby v Myers [1867] LR 2 CP 651.

${ }^{30}$ Krell v Henry [1902] 2 KB 740.

${ }^{31}$ Due to the postponement of the coronation numerous actions were brought before the courts. These are the so- called coronations cases, which are landmark cases regarding the evolvement and development of the theory of frustration of performance. These cases are reviewed and analysed by McElroy and Williams in their two-part study, in which they pay particular attention to Krell $v$ Henry, Herne Bay Steamboat $v$ Hutton (1903] 2 KB 683), and Chandler v Webster ([1904] 1 KB 493). See McElroy-Williams: op. cit.; McElroy, R. G.-Williams, Glanville: The Coronation Cases II. Modern Law Journal, 1941/5, 1-20. (doi: 10.1111/j.14682230.1941.tb00877.x).

32 Wade, William: Consensus Mistake and Impossibility in Contract. The Cambridge Law Journal, 1941/3, 366. (doi: 10.1017/s0008197300126091). 
concluded in his referred work, "all points which are within the contract as agreed by the parties are part of the subject-matter of the contract, and all points which are outside of it go at most to motive and are irrelevant." ${ }^{33}$

Briefly, in Krell v Henry the contract did not become impossible, but the purpose of the contract was frustrated, for which the contract was concluded. In this sense, the doctrine of frustration of contract was more broadly interpreted. ${ }^{34}$

It is also important that frustration covers both the frustration of performance of contract and the frustration of purpose (of contract) in English law. Conversely, the examined expression means only the frustration of purpose in the American law, i.e. it has a narrower interpretation, ${ }^{35}$ at which the commercial impossibility and impracticability appear as independent category. ${ }^{36}$

\subsection{Chandler v Webster}

As it was previously mentioned, due to the postponement of the coronation numerous actions were brought before the courts, among which Krell $v$ Henry is undoubtedly the best-known. However, another case, Chandler v. Webster ${ }^{37}$ is also worth reviewing, despite the fact that later it was overruled. ${ }^{38}$ Thus, it was a landmark case for almost forty years in those cases, where payments or expenditures made prior to the occurrence of the contract-frustrating event had to be treated. ${ }^{39}$

According to the facts described, Chandler rented a room from Webster for the first day of the coronation procession with the intention of erecting a stand and selling tickets. The money was all due prior to the postponement of the coronation.

33 Ibid.

${ }^{34}$ The Krell v Henry was elaborated by Zoltán Csehi in his work relating to impossibility. See Csehi, Zoltán: 'A király megbetegedett:' a szerződés lehetetlenül. Az idő dimenziója a lehetetlenülés körében - az időszakos lehetetlenülés problémája. In: Emlékkönyv Lontai Endre egyetemi tanár tiszteletére, ELTE-ÁJK-Gondolat, Budapest, 2005, 37-52.

${ }^{35}$ Momberg: op. cit., 139; Corbin, Arthur L.: Recent Developments in the Law of Contracts. Harward Law Review, 1937/1, 464-466. (doi: 10.2307/1333316); Anderson, Arthur: Frustration of Contract - A Rejected Doctrine. DePaul Law Review, 1953/1, 1-22; Hubbard, Steven W.: Relief from Burdensome Longterm Contracts: Commercial Impracticability, Frustration of Purpose, Mutual Mistake of Fact, and Equitable Adjustment. Missouri Law Review, 1982/1, 83-84; Eisenberg: op. cit., 210, 233.

${ }^{36}$ In this context see Walter, Paula: Commercial Impracticability in Contracts. St. John's Law Review, 1987/2, 225-260; Posner, Richard A.-Rosenfield, Andrew M.: Impossibility and Related Doctrines in Contract Law: An Economic Analysis. The Journal of Legal Studies, 1977/1, 83-118. (doi: 10.1086/467564); Dellinger, Myanna: An "Act of God" - Rethinking Contractual Impracticability in an Era of Anthropogenic Climate Change. Hastings Law Journal, 2016/6, 1551-1620.

${ }^{37}$ Chandler v Webster [1904] 1 KB 493.

38 The Chandler v Webster ([1904] 1 KB 493) was overruled in the Fibrosa Spolka Akcyjna v Fairbairn Lawson Combe Barbour Ltd HL ([1943] AC 32). About this latter judgment see Williams, Glanville L.: The End of Chandler v Webster. The Modern Law Review, 1942/1-2, 46-57. (doi: 10.1111/j.1468-2230.1942.tb02865.x).

${ }^{39}$ In its relating study, Goldberg examines and reviews the Chandler v Webster from a special point of view, when he compares the English and American rules and criticises the approach, according to which the application of Chandler v Webster is totally refused. See Goldberg, Victor Paul: After Frustration: Three Cheers for Chandler v. Webster. Columbia Law and Economics Working Paper, No. 382, 1133-1169. (doi: 10.2139/ ssrn.1703123). 
Chandler paid almost the whole sum of money and after the postponement he sued for return of his money paid. Webster counterclaimed for the remainder. Chandler's claim was rejected and Webster could keep the prepaid sum and was entitled to the remainder of the sum that had been agreed. The Court of Appeal held that money paid under a contract prior to it being frustrated could be recovered upon a "total failure of consideration". But, in order to constitute such a situation, the contract had to be set aside from the beginning. As McKendrick points it out, "If]rustration does not have such a consequence. The contract is set aside from the moment of the occurrence of the frustrating event but the termination is not retrospective in its effect." ${ }^{\prime 4}$

\subsection{Legal consequences}

In English law, frustration of contract automatically resulted in the discharge of both contractual parties from the obligation. ${ }^{41}$ However, on the performance of the ongoing duties, or other duties having a repetitive nature, contractual parties usually carried out further negotiations, which resulted in the conclusion of a new contract, which contained new terms and conditions, but did not affect the original contract. In the meanwhile, duties which became due before the occurrence of the frustrating event remained unchanged, in the lack of any relating legal provision. ${ }^{42}$ Moreover, it was also not regulated as to which contractual party takes the responsibility for the damages and loss caused by the change in circumstances.

According to English law, all of the original duties under the contract, including principal and other secondary duties, ceased due to the frustration. The same applied to other duties like obligations relating to the breach of contract or compensation. Accordingly, the general rule was that the party took the liability for damages caused by the frustrating event, who suffered the damage. ${ }^{43}$ However, it was also important, if the contractual consideration was paid in advance or upon the completion of the given work. ${ }^{44}$

The above-mentioned solution applied in English law sometimes placed the contractual parties in an unfair situation. As a striking example, reference can be made to Chandler v Webster, in which the court held that that an obligation to pay, which was due before the time of frustration, was not affected by the frustrating event, therefore residuary payments had to be made and payments previously made could

\footnotetext{
${ }^{40}$ McKendrick, Ewan: Contract Law. Text, Cases and Materials. Oxford University Press, Oxford, 2012, 730. (doi: 10.1093/he/9780199699384.001.0001).

${ }^{41}$ It was confirmed by the judgment in Hiri Mulji v Cheong Yue Steamship Co Ltd., in which it was stated that frustration leads to the termination of contract, whether parties intend this effect or not. Cf. Hirji Mulji v Cheong Yue Steamship Co Ltd [1926] AC 497. In the judgment in Maritime National Fish Ltd v Ocean Trawlers Ltd, the court adopted a similar position. Cf. Maritime National Fish Ltd v Ocean Trawlers Ltd [1935] AC 524.

${ }^{42}$ Cf. Rösler: op. cit., 499; Beale: op. cit., 11; Schmiedlin, Stefan: Frustration of contract und clausula rebus sic stantibus. Eine rechtvergleichende Analyse. Helbing \& Lichtenhahn, Basel und Frankfurt am Main, 1985, $65-66$.

$34{ }^{43}$ Cf. Fibrosa SA v Fairbairn Lawson Combe Barbour Ltd [1943] AC 32.

${ }^{44}$ Cf. Appleby v Myers [1867] LR 2 CP 651.
} 
not be recovered. Although it is true that Chandler v Webster was later overruled in the Fibrosa case, according to which the paid and unpaid considerations could be arranged, this solution treated only the evolved unfair situations, but did not pay attention to the prevention of the contractual party's unjust enrichment due to the frustrating event. ${ }^{45}$

Therefore, partly due to the strong criticism voiced in Fibrosa, ${ }^{46}$ Law Reform (Frustrated Contracts) Act (hereinafter referred as to LRA) ${ }^{47}$ was adopted by the Parliament of the United Kingdom in 1943. LRA aimed to provide greater protection to a party who pays a sum of money on the basis of a contractual agreement in circumstances where the contract has been frustrated. Specifically, this would be to remedy the unfortunate situations that had been previously seen in cases such as the above-mentioned Chandler v Webster. For this purpose, LRA contains detailed provisions on the rights and obligations relating to the contracts affected by a frustrating event. ${ }^{48}$ With the adoption of the LRA, the Parliament primarily intended to prevent the contractual party's unjust enrichment due to the frustration of fulfilment or frustration of purpose of the contract. ${ }^{49}$ For this reason, LRA declares that "[a]II sums paid or payable to any party in pursuance of the contract before the time when the parties were so discharged ('the time of discharge') shall, in the case of sums so paid, be recoverable from him (...)." However, this provision is applicable only in those cases where, due to the frustrating event, both parties are discharged from the performance of their contractual duties. In all those cases, where only either of the parties is discharged, legal consequences will be applied according to the principles previously evolved in the judicial practice.

It should also be noted that that the application of the LRA is excluded in certain cases, e.g. it shall not apply to certain types of contracts determined by law. With some exceptions, such contracts include the carriage of goods by sea, any contract of insurance and any other contract for the sale, or for the sale and delivery, of specific goods, where the contract is frustrated by reason of the fact that the goods have perished. ${ }^{50}$

${ }^{45}$ Cf. Meier, Sonja: Unjust factors and legal grounds. In: Johnston, David-Zimmermann, Reinhard (eds.): Unjustified Enrichment: Key Issues in Comparative Perspective. Cambridge University Press, Cambridge, 2002, 66. (doi: 10.1017/cbo9780511495519.003).

${ }^{46}$ Stewart, Andrew-Carter, J. W.: Frustrated Contracts and Statutory Adjustment: The Case for a Reappraisal. The Cambridge Law Journal, 1992/1, 76. (doi: 10.1017/s0008197300016779).

47 Law Reform (Frustrated Contracts) Act, 1943.

${ }^{48}$ About the provisions of the LRA see Williams, Glanville, L.: The Law Reform (Frustrated Contracts) Act, 1943. Modern Law Review, 1944/1-2, 66-69; Stewart-Carter: op. cit., 79-82; Schmiedlin: op. cit., 69-86.

${ }^{49}$ Before the adoption of LRA, unjust enrichment arisen due to the frustrating event, was severally discussed in the contemporary literature. See Buckland, William Warwick: Casus and Frustration in Roman and Common Law. Harvard Law Review, 1933/8, 1281-1300. (doi: 10.2307/1331622); Gutteridge, Harold. C.-Lipstein, Kurt: Conflicts of Law in Matters of Unjustifiable Enrichment. The Cambridge Law Journal, 1939/1, 80-93. (doi: $10.1017 / \mathrm{s} 0008197300127576)$. However, the problem was also examined in the later literature. See Baker, John H.: Frustration and Unjust Enrichment. The Cambridge Law Journal, 1979/2, 266-270.

${ }^{50}$ Cf. LRA, Article 2, paragraph (5), point a)-c). 


\section{The theory of frustration in the recent judicial practice}

The above-mentioned precedents are definitely landmark cases in the course of the development of the doctrine of frustration of contract. However, treating the impacts of the changes of circumstances arises time and again. New situations arise and new judgments were born, by which the original doctrine has further been refined and shaded, even the LRA contains provisions.

The doctrine of frustration of contract received a different, but also exact description in the case of Davis Contractors v Fareham Urban UDC. ${ }^{51}$

According to the facts described, Davis Contractors agreed with Fareham Urban District Council to erect 78 houses within a period of eight months, at a price of $£ 92,425$. The work started in June 1946, but due to various reasons (e.g. serious shortage of skilled labour and materials in the industry), it took not eight but 22 months and was completed only in May 1948. Moreover, the completion of the work was much more expensive than anticipated. Davis Contractors were paid the contractually agreed price but brought an action arguing for more money based on the fact that the contract had been frustrated and therefore they were entitled to further payment based on a quantum meruit basis.

The court recognised that the obligor's duty to perform the contract became more difficult to perform due to the change of circumstances, i.e. the lack of skilled labour and materials. However, it formulated that the contract was not frustrated. At this point the opinion of Lord Radcliffe shall be highlighted, in which he attempted to define the frustration of contract in the following way: "(...) frustration occurs whenever the law recognises that, without the default of either party, a contractual obligation has become incapable of being performed because the circumstance in which performance is called for would render it a thing radically different from that which was undertaken by the contract." 52 This approach was later confirmed by other judgments, for instance in Tsakiroglou \& Co Ltd v Noblee Thorl $\mathrm{GmbH}^{53}$ and in National Carriers Ltd $\checkmark$ Panalpina (Northern) Ltd. ${ }^{54}$ In the latter case it was held that the doctrine of frustration is also applicable to leases in exceptional circumstances, although a lease is more than a simple contract.

Regarding all the above-mentioned facts, that there are cases when the literal compliance of contract conditions (e.g. contractual price) would be unfair for both parties in light of the new (changed) circumstances, in such a situation the law relieves both contractual parties from the duty to perform the contract. ${ }^{55}$

Relating to the doctrine of frustration of contract, J. Lauritzen AS v Wijsmuller BV (The Super Servant Two ${ }^{56}$ is also a landmark case.

${ }^{51}$ Davis Contractors Limited v Fareham Urban District Council [1956] AC 696.

${ }^{52}$ Davis Contractors Limited v Fareham Urban District Council [1956] AC 696. Cf. Collins, Hugh: The Law of Contract. Cambridge University Press, Cambridge, 2003, 298.

${ }^{53}$ Tsakiroglou \& Co Ltd v Noblee Thorl GmbH [1962] AC 93.

${ }^{54}$ National Carriers Ltd v Panalpina (Northern) Ltd [1981] AC 675.

${ }^{55}$ Cordeiro, A.B. Menezes: Brexit as an Exceptional Change of Circumstance? In: Cabral, Nazaré da CostaGonçalves, José Renato-Rodrigues, Nuno Cunha (eds.): After Brexit. Consequences for the European Union. Palgrave Macmillan, Cham, 2017, 154. (doi: 10.1007/978-3-319-66670-9_8).

${ }^{56}$ J. Lauritzen AS v Wijsmuller BV (The Super Servant Two) [1990] 1 Lloyd's Rep 1. 
According to the facts described, the defendant Wijsmuller agreed to transport the plaintiff's large and heavy drilling rig, named Dan King, from Japan to the Rotterdam area of the North Sea, using a transportation unit, described as Super Servant One or Super Servant Two. These were large, self-propelled, semi-submersible barges built for carrying large loads such as this rig. Under the contract, the defendant could replace the transportation unit by other means of transport or cancel the contract on grounds determined in the contract. Such events were the force majeure, acts of God, perils or danger and accidents of the sea, acts of war or warlike-operations, acts of public enemies, blockade, strikes, etc., which reasonably may impede, prevent or delay the performance of this contract.

In January, 1981, several months before Dan King was due to be tendered for carriage, Super Servant Two foundered and became a total loss in the course of off-loading another drilling rig in the Zaire River. Wijsmuller informed Lauritzen, that they would not carry out the transportation of the rig with either Super Servant One or Super Servant Two. Wijsmuller alleged that Super Servant Two would have been used for the Dan King carriage contract. It was added, that the other vessel, Super Servant One, had been scheduled to carry, and did carry, cargo under two other contracts spanning the expected period of performance under the Dan King contract.

Wijsmuller and Lauritzen entered into new negotiations, which led to a further agreement in April 1981 under which the rig was transported by Wijsmuller between July and October by barge and tug. This different method of carriage caused both of the parties' loss or increased expense, therefore both parties claimed for the loss it has suffered. In the action, Lauritzen claimed damages for breach of the Dan King carriage contract, while Wijsmuller pleaded that the contract had been frustrated and claimed for the extra costs arose by the performance of the contract.

The court of first instance ruled in favour of the plaintiff, who appealed to the Court of Appeal. The appeal was dismissed by Lord Justice Bingham. In his judgment he resumed the essential elements of the frustration of contract and defined its special conditions in the given case. According to the judgment, the contract was not frustrated, because Wijsmuller's chance to perform the carriage contract physically still remained after the sinking of the Super Servant Two. In any case, Wijsmuller put its own interests above the other party's when considering economic and business policy aspects, deciding to perform another existing contract, and, with this act, booked the other vessel, which was also specified in the carriage contract and which would also be suitable for transporting Lauritzen's rig. In the judgment it was stated that the frustration of contract can occur only in case of a certain external event or change in circumstances, i.e. frustration cannot be based on the conduct or the choice of the party claiming frustration. Moreover, this party cannot contribute ${ }^{57}$ to the occurrence of the frustrating event. ${ }^{58}$

${ }^{57}$ The contribution of the party claiming frustration to the occurrence of the frustrating event was also examined by the court in DGM Commodities Corporation $v$ Sea Metropolitan SA. As it was formulated in the findings of the judgment, the party's contribution shall be interpreted broadly; it does not require the party's wrongful conduct, but the active conduct of the party or of other person representing the party is enough to state the contribution. See DGM Commodities Corporation v Sea Metropolitan SA [2012] EWHC 1984.

58 The case was reviewed and criticised by Hedley, Steve: Carriage by Sea. Frustration and Force Majeure. The Cambridge Law Journal, 1990/2, 209-211. (doi: 10.1017/s0008197300116940). 
The frustration of contract was also examined by the court in Gamerco SA v ICM/ Fair Warning (Agency) Ltd..$^{59}$ Gamerco, a Spanish company agreed with the corporate persona of the American rock band Guns N' Roses to organise a concert in the stadium Atletico Madrid. Beyond the concrete organising tasks, Gamerco also agreed to manage the previous promotion of the event. A few days before the concert, engineers reported the venue was structurally unsound and the competent authorities banned its further use pending further investigations. At the same time, Gamerco's license to use the venue was revoked. Since there was no chance to use another appropriate venue, the concert finally was cancelled. Gamerco brought an action against the band and claimed the recovery of the sum of 412,500 dollars, which was previously paid by Gamerco. In its judgment the court stated that the contract was frustrated, because the performance of the contract became impossible due to the revocation of the permit by the competent authority. Therefore, the band was obliged to recover the sum paid.

In Sea Angel, ${ }^{60}$ the frustration of contract also was stated by the court. As evidenced by the facts of the case, in the summer of 2003, the Tasman Spirit, a tanker loaded with light crude oil, run aground and was broken in two near the port of Karachi, Pakistan. Due to the accident, large quantities of crude oil spilled from the tanker, causing significant marine oil pollution.

Tsavrilis, a group dedicated to saving life and property at sea and to protecting the marine environment from accident-related pollution, concluded a contract with the owners of the Tamsan Spirit to assist in the salvage operation concerning the tanker. In order to perform the contract, Tsavrilis concluded further contracts and hired several vessels. One of them, the Sea Angel had the task to act as a shuttle tanker and to carry the oil from the damaged Tasman Spirit to a larger tanker. The Sea Angel was hired for twenty days, but the vessel arrived at the location about three months after the expiry of the contract. The delay was due to the fact that the vessel was withheld by the authorities in the port of departure. (As it was later proved, the authorities' conduct was unlawful.) Tsavrilis refused to pay the fee for the time after the expiry of the contract.

The claimants took legal action to recover the hire fees. The Queen's Bench ruled in favour of the claimants and stated that the contract was not frustrated. On the one hand, the risk of detention is well-known and typical in the salvage industry, and it is inherent in such contracts, therefore Tsavrilis should have taken it into account as reasonable risk, i.e. this risk was foreseeable. On the other hand, the risk of delay falls within the scope of contractual risks, which should be taken by the hirer, Tsavrilis. Tsavrilis appealed to the Court of Appeal, which dismissed the appeal. As Lord Justice Rix stated, "(...) the application of the doctrine of frustration requires a multi-factorial approach. Among the factors which have to be considered are the terms of the contract itself, its matrix or context, the parties' knowledge, expectations, assumptions and contemplations, in particular as to risk, as at the time of

${ }^{59}$ Gamerco SA v ICM/Fair Warning (Agency) Ltd [1995] 1 WLR 1226.

${ }^{60}$ Edwinton Commercial Corporation \& Anor v Tsavliris Russ (Worldwide Salvage \& Towage) Ltd (The Sea Angel) [2007] EWCA Civ 547. 
contract, at any rate so far as these can be ascribed mutually and objectively, and then the nature of the supervening event, and the parties' reasonable and objectively ascertainable calculations as to the possibilities of future performance in the new circumstances." Some of these factors exist at the time of the contract. These factors, i.e. the terms of the contract, its matrix or context, and the parties' knowledge, expectations, assumptions and contemplations, in particular as to risk, can be called ex ante factors. The other factors, such as the nature of the supervening event and the parties' reasonable and objectively ascertainable calculations as to the possibility of future performance in the new circumstances, are post-contractual. The "multi-factorial approach" drafted by LJ Rix, was endorsed on several occasions in recent years. ${ }^{61}$

Moreover, beyond the necessity of this "multi-factorial approach" required by the doctrine of frustration, LJ Rix referred to the reasons held by Lord Radcliffe in Davis Contractors Ltd v Fareham UDC and explained, why the test of "radically different" is important. According to LJ Rix, this test "(...) tells us that the doctrine is not to be lightly invoked; that mere incidence of expense or delay or onerousness is not sufficient; and that there has to be as it were a break in identity between the contract as provided for and contemplated and its performance in the new circumstances." 62

\section{Brexit as a frustrating event?}

The political changes of the last few years showed several situations, where the assessment of a certain change as frustrating event is controversial at present.

Among these examples, Brexit, i.e. the withdrawal of the United Kingdom from the European Union had special importance, since it has a strong impact on contracts and their performance. Thus, after the occurrence of Brexit exchange rate changes can occur or various taxes and duties can be introduced, due to which the profitability of the previously concluded (i.e. at the time of Brexit already existing) contracts can decrease. Moreover, the fact that the fundamental freedoms guaranteed by EU law such as free movement of goods and services will no longer prevail, causes further difficulties in the case of the performance of existing contracts.

In the beginning several opinions appeared relating to the performance of contract. Some experts said that there would be cases where the performance of the contract would become impossible or the maintenance of the contract no longer would be in the interest of either or both of the parties due to Brexit. According to Lehmann and Zetzsche, such a situation would arise when an English law firm provides advisory services regarding EU subsidies for an investment in the UK. Since these subsidies will no longer be available after Brexit the service promised will become aimless. ${ }^{63}$

\footnotetext{
${ }^{61}$ See Islamic Republic of Iran Shipping Lines v Steamship Mutual Underwriting Association (Bermuda) Ltd (Rev 1) [2010] EWHC 2661 (Comm), point 110 and 114; Bunge SA v Kyla Shipping Company Ltd [2012] EWHC 3522 (Comm), point 67.

62 Judgment in "The Sea Angel” [2007] EWCA Civ 547, point 111.

${ }^{63}$ Lehmann, Matthias-Zetzsche, Dirk: Brexit and the Consequences for Commercial and Financial relations between the EU and the UK. European Business Law Review, 2016/27, 1007. (doi: 10.2139/ssrn.2841333).
} 
Nevertheless, it was a general opinion that in the majority of cases Brexit would make the performance of the contract more difficult but not impossible. In the course of the assessment of Brexit and its impact, it was also emphaiszed that not every contract would equally be effected by Brexit, but its impact would depend on the type of the given contract. ${ }^{64}$ Accordingly, taking the findings of the previous judgments ${ }^{65}$ into account, referring to Brexit as a frustrating event would be successful very rarely, only in those cases when Brexit would actually cause the essential and radical change of the duties to be performed under an existing contract. ${ }^{66}$ Nevertheless, it cannot be excluded that in certain cases Brexit would give rise to the early, impossibility-based termination of a given contract. ${ }^{67}$

It should also be noted that during the years of the Brexit negotiations between the UK and the EU, more and more contracts were supplemented by a hardship clause in the event of Brexit in the English contract law practice. The insertion of a so-called Brexit clause into the contract enabled the parties to provide for the functioning of their contractual relationship after Brexit. Within the framework of this clause, parties could determine either the automatic changes (e.g. termination of contract) or a procedure whereby discussions are held with a view to changing the contract due to Brexit. Inserting a Brexit clause meant security for the contractual parties. Nevertheless, in all other cases where parties did not insert such a clause, the impact of the Brexit on the existing contractual relationship shall be examined and assessed, and legal consequences will be applied by courts on a case-by-case basis.

With regards to this matter, Canary Wharf (BP4) T1 Ltd \& Ors v European Medicines Agency, ${ }^{68}$ shall be mentioned.

According to the facts of the case, the European Medicines Agency (hereinafter referred to as to EMA), after multiannual negotiations, entered into a lease for a term of 25 years in 2014 with the Canary Wharf Group (hereinafter referred as to $\mathrm{CW}$ ) to secure premises for its headquarters in London. In August, 2017, EMA informed $\mathrm{CW}$ that having considered the position under English law they intend to treat Brexit as a frustrating event. The EMA stated that after the United Kingdom's withdrawal from the European Union the EMA should re-locate away from the UK. As the EMA stated, "Ii]t would be unprecedented and incongruous for an EU body (...) to be Iocated in the UK and continue to pursue its mission in London after the UK has left the EU." ${ }^{69}$ Although Brexit has not occurred yet, in 2018 the EU passed a Regulation that

\footnotetext{
${ }^{64}$ Lehmann-Zetzsche: op. cit., 1010.

${ }^{65}$ Relating to the closure of Suez Canal in 1956, some judgments were handed down in which the court held that the Suez Crisis shall not be deemed as frustrating event, since the existing contracts were finally performed with significant time delays. See Albert D. Gaon \& Co. v. Societé Interprofessionelle des Olégiaux Fluides Alimentaires [1959] 2 Lloyd's Rep. 30; Société Franco Tunisienne D'Armement v. Sidermar S.P.A. [1960] 3 W.L.R. 701; Tsakiroglou \& Co Ltd v Noblee Thorl GmbH [1962] AC 93. About the facts, the findings of judgments and the legal arguments see Furmston, Michael: Contract Frustrated. Then Performed! The Modern Law Journal, 1961/1, 173-178.

${ }^{66}$ Cordeiro: op. cit., 161.

${ }^{67}$ In its relating work, Catharine MacMillan examines the effects of Brexit upon English contract law. See MacMillan, Catharine: The Impact of Brexit upon English Contract Law. King's Law Journal, 2016/3, 420-430. (doi: 10.1080/09615768.2016.1250468).

68 Canary Wharf (BP4) T1 Ltd \& Ors v European Medicines Agency [2019] EWHC 335 (Ch) (20 February 2019).

${ }^{69}$ Quotation from the EMA's letter of 2 August 2017.
} 
relocated the EMA headquarters from London to Amsterdam. CW brought a claim against the EMA and disputed that Brexit would be a frustrating event. The EMA argued that the contract was frustrating on the grounds of supervening illegality, since it would not be legally possible for it to continue with its headquarters in London as it did not have legal capacity to hold or deal with immovable property outside the EU. On the other hand, EMA also it also relied upon the frustration of a common purpose.

The court decided in favour of CW and found that the lease would not be frustrated by Brexit, either because of supervening illegality or frustration of a common purpose. As it was stated, English contract law did not take into account supervening illegality arising under a foreign law (e.g. EU law) when determining whether a contract had been frustrated. Therefore, though EU law may be relevant to the capacity of EMA to enter into the lease, it was not relevant to the question of whether subsequent illegality had caused the lease to be frustrated.

It is important to note that prior to this judgment, it was suggested that a "nodeal Brexit" may constitute the kind of unexpected and serious event that would be classified as a frustrating event. Nevertheless, in spite of the clear reasons of the judgment, far-reaching conclusions must not be drawn, since the case is to be continued before the Court of Appeal, as the EMA appealed against the judgement. Anyway, final judgment of the Court of Appeal could be a landmark case in the future regarding the assessment of Brexit. At the same time, it shall be seen that the United Kingdom's withdrawal from the European Union shall be examined by the court case-by-case, taking all special circumstances, conditions and features of the given case into consideration.

The assessment of Brexit and deeming it as an exceptional event was an important question not only for English law, but all Member States of the EU; both representatives of the literature and legal practice were concerned about the question. Relying on Brexit being a frustrating event can marginally be successful in English law. Nonetheless, there can be another approach outside the UK, in the case of cross-border contractual relationships not governed by English law, since the change of circumstances and the supervening of special events are regulated by law in several state in the European continent.

In connection with the withdrawal of the United Kingdom, Cordeiro concluded that Brexit can be considered as an essential change of circumstances, which can be the basis for the amendment or termination of contract, according to the provisions of the given national (German, French, Italian, etc.) laws.

At the same time, a contrary view seems to have emerged in Germany. The representatives of this approach compare Brexit to German reunification in 1990 and, by invoking the contemporary German judicial practice, does not consider Brexit as an event which would base, in general, the amendment and adaptation of contract on the changed circumstances. Instead of this, it is held that the impacts of Brexit should be assessed in the relationships between British and German business partners case-by-case and in full knowledge of the facts and circumstances. ${ }^{70}$

${ }^{70}$ Cf. Paulus, David: Der „Brexit“ als Störung der „politischen“ Geschäftsgrundlage?: Privat- und Wirtschaftsrecht der Europäischen Union. In: Kramme, Malte-Baldus, Christian-Schmidt-Kessel, Martin (eds.): Brexit und die juristischen Folgen. Nomos, Baden-Baden, 2017, 101-127. (doi: 10.5771/9783845279275-99); 
As can be seen, Brexit can be assessed by the various national laws in different ways. However, the examination of this question goes beyond the applicability of the civil law provisions of the various states. Indeed, the question of the applicable law has to be answered at first. Thus, contractual parties have the right to choose the law to be applied for the given contract.

Although the actual date of Brexit and its conditions has been unforeseeable for a long time, on 31 January, 2020, the United Kingdom left the European Union. Nevertheless, it is not the end of the story, and the impacts of Brexit are still worthwhile examining further. Though Brexit is formally completed, there are several open questions which have an impact on the existing contractual relationships. Ongoing negotiations between the UK and the EU, for instance, on the forms and possibilities for the future trade cooperation, lead to new problems which shall be assessed over time.

\section{Coronavirus: force majeure or a new ground for frustration?}

In the world of international contractual relations, there are certain events which are treated relatively uniformly in the legal practice. For instance, it is beyond any dispute that wars and natural disasters like earthquakes or tsunamis are such events which make the performance of an existing contract not only more difficult, but excuses the contractual party's liability if he cannot perform the contract due to these events. Such events were recently the detrimental earthquake and the subsequent tsunami in eastern Japan in 2011, or the war situation caused by the annexation of the Crimea Peninsula by the Russian Federation in 2014. ${ }^{71}$

However, the most recent factor which can have impact on the performance of international contracts is the outbreak of the novel coronavirus (COVID-19). The measures introduced by the Chinese authorities in order to stop the epidemic (e.g. closure of factories and logistic centres, closing of seaports and airports for an indefinite time) sooner or later will make the performance of contractual obligations impossible for more and more producers and suppliers. In Europe, mass diseases are registrated in Italy, where even larger areas are going under quarantine. More and more organisations announce the cancellation of different events, where masses of people can contract and can potentially pass on the infection, while the closure of borders and the suspension of certain flight destinations also have negative impact on the economy.

At present, it is questionable if the epidemic shall be deemed as a force majeure event upon which the performance of the contract can be suspended or the contract can be terminated, or if it only makes the performance of the contract more difficult,

Mayer, Barbara-Manz, Gerhard: Der Brexit und seine Folgen auf den Rechtsverkehr zwischen der EU und dem Vereinigten Königreich. Betriebs-Berater, 2016/30. https://www.fgvw.de/files/brexit_160725_bb.pdf; 1731-1740. (09. 04. 2019).

${ }^{71}$ As further reading see Kokorin, llya-Van der Weide, Jeroen: Force Majeure and Unforeseen Change of Circumstances. The case of embargoes and currency fluctuations (Russian, German and FrenchApproaches). Russian Law Journal, 2015/3, 46-82. 
i.e. it shall be deemed as a frustrating event. The assessment of coronavirus is especially important in the case of travel contracts, where the time of the conclusion of contract shall be the first feature to be examined regarding the foreseeability of the event, i.e. the outbreak and the globalisation of the epidemic.

By the spread of the epidemic, the number of those who give their opinion is increasing, but there is no univocal answer at present. Although the economic considerations are secondary to the protection of human health, it is obvious that not only the medical aspect of coronavirus shall be treated, but legal solutions shall be defined, upon which the economic and legal risks caused by the epidemic can be treated. However, it should be mentioned that in international contractual relationships the assessment of coronavirus as frustrating or force majeure event will also depend on the law applicable to the parties' contract. It should also be added that the assessment of other epidemics, like the outbreak of the Ebola epidemic in 2014 also can help in providing an answer. ${ }^{72}$ At present, it is unpredictable if coronavirus will spread around the world and the epidemic transform into a pandemic. Nevertheless, it is clearly visible that the epidemic has serious impacts on the economy in the different continents, which spill over increasingly. These negative consequences can only be measured by the effects of the economic crisis in 2008, therefore national legislators and actors of the legal practice shall prepare for the treatement of the change of circumstances due to the epidemic and shall take a stand on this issue.

\section{Closing remarks}

After the brief review of the relating precedents, it can be stated that English law recognises the effect of the change of circumstance, that is, a supervening event, on the contractual relationship. The frames of the evaluation of such changes are designated by both the LRA and the judicial case law. Nevertheless, it also shall be stated that in English law, contrary to continental national laws, change of circumstance does not give rise to the amendment of the contract. Instead of this, there is two ways for the evaluation of the impacts of the changes in circumstances subsequent to the conclusion of the contract. ${ }^{73}$ The legal status of the contract existing between the parties depends on the measure and the intensity of the changes in circumstances.

If the change in circumstances results in the essential change of the contract, due to which the contractual duty cannot be performed, the contract is frustrated and both parties are discharged from the performance of the contract. If the change in circumstances was less significant, contractual parties remain bound by their agreement, i.e. the binding force of contract ("sanctity of contract") prevails in their relationship and the contractual duties shall be performed. Otherwise, parties can diverge from

\footnotetext{
${ }^{72}$ Cf. Polkinghorne, Michael-Rosenberg, Charles B.: The Ebola Epidemic and Force Majeure: Expecting the Unexpected. Alternatives to the High Cost of Litigation, 2014/11, 165-178. (doi: 10.1002/alt.21557).

${ }^{73}$ Pichonnaz, Pascal: From Clausula Rebus sic Stantibus to Hardship: Aspects of the Evolution of the Judge's Role. Fundamina, 2011/17, 139. (doi: 10.4000/books.pusl.1034).
} 
this rule if their contract contained a hardship clause for the case of an occurrence of a change in circumstance after the conclusion of the contract. Briefly, a frustrating event is one which occurs after the conclusion of the contract and which is so fundamental as to go to the root of the contract, which is neither party's fault and renders further performance impossible, illegal or makes it radically different from that which was contemplated by the parties at the time the contract was made.

Summarising the previously cases, it shall be noted that the doctrine of frustration of contract is the only legally clearly justified approach in English law which takes the impacts of the change in circumstances into account. ${ }^{74}$ According to the theory, a contractual party is relieved from the duty to perform the contract if, due to the change in circumstances, the performance of the contract became impossible, or the purpose of the contract has been frustrated. In this latter case, the parties' interest in the performance of the contract also ceases due to the frustration of purpose.

Nevertheless, as was previously mentioned, the scope of the frustrating events is not closed; various cases and frustrating events are drafted by the judicial practice.

As Beale noted in its previously referred work, the theory of frustration of contract, in accordance with the strict approach of the English courts towards the "sanctity of contracts", the effects of change in circumstances on the contractual relations are recognised within strict limitations. Therefore, frustration of contract can be caused by either of the cases of impossibility, but cannot be per se based on the fact that the performance of the contract became commercially impracticable due to the change of circumstances. Under English law, the establishing of the termination of contract upon frustration is the ultimate solution applied by the courts, while other principles, like the parties' freedom to contract and the sanctity of contract, i.e. the observance of the terms agreed by the parties, still take precedence at the present time. ${ }^{75}$

Nonetheless, by mean of their above-mentioned freedom, contractual parties are allowed to insert special terms in their contract by which they determine the legal consequences to be applied in case of particular events like force majeure, Brexit or the spread of a certain epidemic. Thus, frustration is not available where the contract has otherwise made express provision for the consequences of the occurrence of a certain event. In these cases, the question of frustration does not arise in the parties' relations, but the contract shall be assessed by the application of the given clause.

${ }^{74}$ Cf. Beale: op. cit., 11.

${ }^{75}$ Papp, Tekla: Frustration and Hardship in Contract Law from Comparative Perspective. Acta Universitatis Szegediensis, 2014, 423. 